\title{
Method of Transosseous Through-and-Through Drainage of Bone Cysts
}

\author{
DOI: $10.17691 / \mathrm{stm} 2016.8 .2 .10$
}

Received February 9, 2016

\begin{abstract}
V.E. Shelyakhin, PhD Student, Department of Pediatric Orthopedics;
M.V. Vlasov, MD, PhD, Leading Researcher, Head of the Department of Pediatric Orthopedics;

N.A. Tenilin, MD, DSc, Leading Researcher, Department of Pediatric Orthopedics

Privolzhsky Federal Research Medical Center, Ministry of Health of the Russian Federation,

18 Verkhne-Volzhskaya naberezhnaya St., Nizhny Novgorod, 603155, Russian Federation
\end{abstract}

The aim of the investigation was to develop a method of treatment of degenerative bone cysts localized in the double-beam segments of the limbs.

Materials and Methods. We proposed a method of through-and-through drainage of degenerative bone cysts in double-beam segments of the limbs with the insertion of puncture needles through the unaffected radius. The transosseous introduction of the needles is achieved under a certain angle of osteoperforation: the distal needle - under the 15 to $30^{\circ}$ posterior angulation, and the proximal needle under 15 to $30^{\circ}$ anterior angulation. The needles are arranged in the following way: the distal one is placed in the anteroinferior part of the cyst, and the proximal one is placed in the posterosuperior part of the cyst more distally from the enostosis, that apart from secure fixation enables the overall irrigation of the cavity of the pathological focus.

The proposed method is applied to 8 patients with localization of the pathological process in the bones of the lower leg and forearm. Transosseous drainage was carried out for 7-10 days with successive change of the perfusion drugs.

Results. The needle fixation in all patients was good, the outflow of the therapeutic mixture into the surrounding soft tissues was not observed. During the drainage the patients did not complain, no complications were observed.

Conclusion. The transosseous method of through-and-through drainage of bone cysts enables to achieve secure fixation of puncture needles and avoid complications.

Key words: bone cysts; transosseous drainage; double-beam segment of the limb.

No final solution to the problem of treatment of bone cysts has been found yet [1-4].

A number of authors relate increased intraosseous pressure, resulted from circulatory disorders in the limited areas of bone, to the main link in the pathogenesis of bone cysts [5]. Others argue that the cyst arises as a result of degenerative process in the primarily dysplastic bone tissue $[6,7]$. A tumor theory of the origin of bone cysts has not been confirmed. Local circulatory disorders in the juxtaphyseal bone areas that are most unfavorable for compensatory vessel remodeling and leveling of increased intraosseous pressure, lead to bone necrosis. Later the most complex processes of homeostasis disorders are triggered, accompanied by a local increase in the activity of the lysosomal proteolytic enzymes, fibrinolysis and a sharp increase in hydrostatic pressure, which is maintained by a constantly functioning vicious circle of events that exacerbate one another [8-13].

The approaches to operative treatment have changed significantly in time and now surgery in the management of bone cysts can be divided into two groups: boneplastic and puncture treatment $[13,14]$.
Bone-replacement plastic surgery is traumatic and it is associated with long-term transplant restructuring and numerous complications such as shortening development, false joints, deformity and muscle wasting $[15,16]$. The current trend involves withdrawal of resection bone plastic surgery. However, in modern publications, quite a number of authors show their commitment to the surgical intervention of this kind [17].

The puncture treatment method was proposed by the Italian orthopedist Oscar Scaglietti, who in 1962 was the first to perform puncture of a bone cyst and introduce hormones into the cavity [18]. Later, the puncture method underlay a noninvasive treatment technique developed at the Central Research Institute of Traumatology and Orthopedics named after N.I. Priorov (Moscow). The concept of the method involves step-by-step successive punctures of the cyst and the introduction of medication into its cavity $[19,20]$. However, this method has a number of drawbacks: long-term treatment; the need for a series of punctures (4-5) at intervals of 1 to 4 weeks; closing of the cyst cavity in the period from 2 to 8 years;

For contacts: Vladimir E. Shelyakhin, e-mail: shelyahin@mail.ru 
persistence of a high risk of pathologic fracture during treatment and rehabilitation.

The fractional puncture method was advanced by scientists of the Nizhny Novgorod Institute of Traumatology and Orthopedics in 1995, they proposed permanent through-and-through cavity drainage of cysts. The method comprises a continuous permanent lavage of the cavity with the successive use of medication [21]. The drainage time is 712 days.

During the through-and-through drainage particular attention is paid to the cortical layers of the bone in the cyst area. Successful procedure directly depends upon the degree of their thinning. The problem of draining a cyst cavity with pronounced thinning of the cortical layer when the stability of needle installation fails has not been solved yet. The extreme degree of cortical thinning is more common when cysts are localized in the bones of the double-beam segments of the limbs, due to the "reinforcing" effect of the unaffected radius. In this case, a pathological fracture occurs later than in a similar situation when a pathological focus is localized in the single-beam segment of a limb.

The aim of the investigation was to develop a method of treatment of degenerative bone cysts localized in the double-beam segments of the limbs.

Materials and Methods. The method of transosseous through-and-through drainage of bone cysts in the double-beam segments of a limb comprises directing puncture needles through the unaffected radius, which enables for their stability. This method was used in 8 children, 6 of them having aneurysmal cysts, 2 having solitary cysts. In 4 patients the cyst was localized in the fibula, in 3 of them - in the tibia, and 1 patient had a cyst in the ulna. In all the patients the cortical bone layer in the cyst area was pronouncedly thinned. The study was conducted in accordance with the Declaration of Helsinki (adopted in June 1964 (Helsinki, Finland) and revised in October 2000 (Edinburgh, Scotland)) and approved by the Ethics Committee of the Privolzhsky Federal Research Medical Center. The informed consent was received from the patients' parents.

The proposed method was performed in the following way. Two skin incisions of up to $1 \mathrm{~cm}$ long were made in the bone cyst projection on the contralateral side above the unaffected bone. The incisions were made in the projection of the upper and lower cysts poles. The access to the bone was performed in a blunt way. Controlled by the electron-optical converter drill with the diameter equal to $1 / 8$ of the diameter of the size across the bone, osteoperforational apertures were performed in the unaffected radius, penetrating the both cortical layers, the distal canal formed at an angle of 15 to $30^{\circ}$, open posteriorly, and the proximal one formed at the angle from 15 to $30^{\circ}$, open anteriorly.

The angle of needle installation is determined by the size of a cyst: the more the swelling of the bone in the cyst area, the more the osteoperforation angle is to direct a needle into the most injured area of the bone and it should be of $30^{\circ}$. Exceeding $30^{\circ}$ angle creates a higher risk of paraosseal directing of the intraosseous needle. Choosing an angle of less than $15^{\circ}$ decreases the stability of the needle installation in the formed canal of the unaffected radius. The maximum possible distance of the apical ends of the needles relative to each other provides a more complete irrigation of the cyst cavity with medication.

The puncture needles with the diameter of $1 \mathrm{~mm}$ less than the diameter of the osteoperforation drill are installed in the formed intraosseous canals and arranged in the following way: the distal one is placed in the anteroinferior part of the cyst, and the proximal one is placed in the posterosuperior part of the cyst more distally from the enostosis (See the Figure). The lavage of the pathological focus cavity is performed with saline solution and aminocaproic acid solution to the "pure" water. The inflow-outflow cyst perfusion system is arranged.

Results. Transosseous drainage was carried out for 7-10 days with a succession of perfusion products. The needle fixation in all patients was good, the outflow of the therapeutic mixture into the surrounding soft tissues was not observed. During the drainage the patients did not complain, no complications were observed.

\section{Case report.}

Patient B., 8 years old was admitted to the Department of Pediatric Orthopedics of the Privolzhsky Federal Research Medical Center, diagnosed with "aneurysmal cyst of the lower third of the right ulna". From the past history: he has been treated since he was two years old. The repeated attempts of throughand through drainage through the affected radius were not successful, and the treatment was restricted to the puncture method. Three pathological fractures without significant displacement of the fragments at a minor injury were observed

At admission, during the examination we observed a deformation of the lower third of the forearm due to the "swelling" of the lower third of the ulna, ulnar deviation of the wrist was limited to $0-2^{\circ}$, flexion movements $30 / 0 / 40^{\circ}$. The skin over the swelling was erythematous, with moderate pain. The radiographs revealed a marked swelling of the lower third of the ulna due to the pathological focus of a lytic type, size $8 \times 5 \times 4 \mathrm{~cm}$, the cortical layers were extremely thinned (less than $1 \mathrm{~mm}$ ). The distal margin of the focus was the zone of the ulna growth.

The patient was operated by the proposed method. During the intermediate examination 3 months later the deformity of the forearm was found to decrease, ulnar deviation of the wrist increased up to $10^{\circ}$, the radiographs demonstrated the recovery of the cortical 

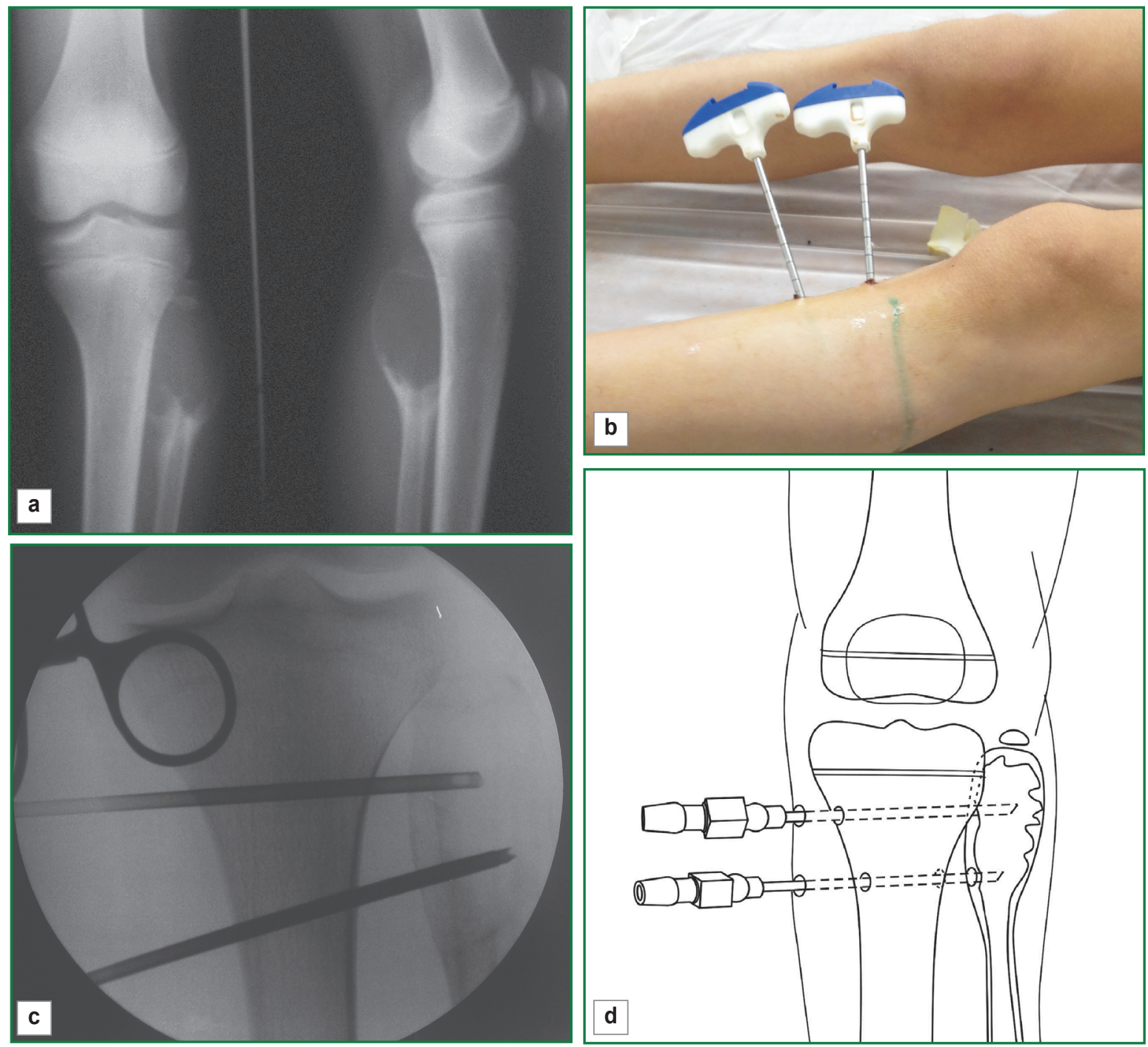

Transosseous drainage of the fibula in patient U., 14 years old: (a) aneurysmal cyst of the fibula with extreme thinning of the cortical layer; (b) puncture needles installed transossally; (c) a photoradiograph, transosseous drainage with two intraosseous needles; (d) a schematic image of needle installation

layer to $2 \mathrm{~mm}$ in the whole length of the cyst and the beginning of the cyst cavity repair at the site of needle passing with the formation of a cellular structure.

At the checkup 1 year after the surgery the swelling of the ulna was not visually determined, the wrist joint had a full amount of motion, the radiographs demonstrated marked active cyst reparation: the $5 \times 2 \times 2 \mathrm{~cm}$ size of the pathological focus, the restored cortical layers, multiple bridges in the cyst cavity, the density of bone tissue in the cyst area close to normal.

Conclusion. The method of transosseous throughand-through drainage of the cysts in double-beam bone segments of the limbs enables to improve the fixation of intraosseous needles in the cavity of the cyst with the utmost degree of thinning of the cortical bone layer and avoid complications.
Study Funding and Conflicts of Interest. The work was not supported by any sources, and there is no conflicts of interest related to this study.

\section{References}

1. Demichev N.P., Tarasov A.N. Diagnostika i kriokhirurgiya kostnykh kist [Diagnosis and cryosurgery of bone cysts]. Moscow: MEDpress-inform; 2005; 144 p.

2. Snetkov A.I. Opyt diagnostiki i lecheniya kist kostey u detey. $\mathrm{V}$ kn.: Materialy tret'ego Rossiyskogo nauchnogo foruma "Khirurgiya 2001" [Experience of diagnosis and treatment of bone cysts in children. In: Proceedings of the third Russian scientific forum "Surgery 2001"]. Moscow; 2001; p. 207-208.

3. Altermatt S., Schwöbel M., Pochon J.P. Operative treatment of solitary bone cysts with tricalcium phosphate ceramic. A 1 to 7 year follow-up. Eur J Pediatr Surg 1992; 2(3): 180-182, http://dx.doi.org/10.1055/s-2008-1063435. 
4. Albrektsson T. Hydroxyapatite-coated implants: a case against their use. J Oral Maxillofac Surg 1998; 56(11): 13121326, http://dx.doi.org/10.1016/s0278-2391(98)90616-4.

5. Tenilin N.A., Bogos'yan A.B., Sosnin A.G. The treatment of degenerative bone cysts. Travmatologiya $i$ ortopediya Rossii 1995; 5: 27-30.

6. Andreev P.S. Diagnostika $i$ lechenie anevrizmal'nykh kostnykh kist dlinnykh kostey u detey. V kn.: Aktual'nye voprosy detskoy travmatologii $i$ ortopedii [Diagnosis and treatment of aneurysmal cysts of the long bones in children. In: Current issues of pediatric traumatology and orthopedics]. Moscow; 2001; p. 166-167.

7. Althof P.A., Ohmori K., Zhou M., Bailey J.M., Bridge R.S., Nelson M., Neff J.R., Bridge J.A. Cytogenetic and molecular cytogenetic findings in 43 aneurysmal bone cysts: aberrations of $17 p$ mapped to $17 p 13.2$ by fluorescence in situ hybridization. Mod Pathol 2004; 17(5): 518-525, http://dx.doi. org/10.1038/modpathol.3800090.

8. Kuftyrev L.M., Luniova S.N., Pozharishchensky K.E., Zlobin A.V., Yerofeyeva T.N. Biochemical study of blood serum in patients with bone cysts. Geniy ortopedii 2002; 1: 77-80.

9. Amling M., Werner M., Pösl M., Ritzel H., Welkerling H., Wening J.V., Maas R., Winkler K., Heise U., Delling G. Solitary bone cysts. Morphologic variation, site, incidence and differential diagnosis. Pathologe 1996; 17(1): 63-67.

10. Sadof'eva V.I., Gudushauri M.O. Roentgenologic diagnosis of dystrophic cysts in children. Ortopediya, travmatologiya i protezirovanie 1991; 12: 30-32.

11. Mitrofanov A.I., Borzunov D.Yu. Results of treatment in patients with active solitary bone cysts using transosseous osteosynthesis. Geniy ortopedii 2010; 2: 55-59.

12. Watanabe H., Arita S., Chigira M. Aetiology of a simple bone cyst. A case report. Int Orthop 1994; 18(1): 16-19.

13. Ordo Deus. URL: http://www.ordodeus.ru/Ordo_ Deus12_Osteoblastoklastoma.html.
14. Vybornov D.Yu., Borkhunova Ye.N., Koroteyev V.V., Petrov M.A. The etiology, pathogenesis, diagnosis of osseous cysts in children. Detskaya khirurgiya 2003; 1: 34-36.

15. Berchenko G.N. "Solidnyy" variant anevrizmal'noy kisty kosti u detey i podrostkov. V kn.: Aktual'nye voprosy detskoy travmatologii i ortopedii ["Solid" variant of aneurismal bone cyst in children and adolescents. In: Current issues of pediatric traumatology and orthopedics]. Saint Petersburg; 2000; p. 219220.

16. Erol B., Onay T., Çalışkan E., Aydemir A.N., Topkar O.M. Treatment of pathological fractures due to simple bone cysts by extended curettage grafting and intramedullary decompression. Acta Orthop Traumatol Turc 2015; 49(3): 288-296, http://dx.doi.org/10.3944/AOTT.2015.14.0108.

17. Klimovitsky V.G., Zhilitsyn Ye.V., Chuguy Ye.V., Ilyushenko Yu.K., Aleschenko I.Ye. Treatment of bone cysts of different localization in children. Travma 2012; 13(3): 9-11.

18. Scaglietti O., Marchetti P.G., Bartolozzi P. The effects of methylprednisolone acetate in the treatment of bone cysts. Results of three years follow-up. J Bone Joint Surg Br 1979; 61-B(2): 200-204.

19. Berezhnyy A.P., Nechvolodova O.L., Vilenskiy E.V. The outcomes of conservative treatment of solitary and aneurysmal bone cysts in children. Ortopediya, travmatologiya i protezirovanie 1988; 2: 5-7.

20. Burkova L.M. Patogeneticheskoe obosnovanie konservativnogo lecheniya kist kostey $\mathrm{u}$ detey. $\mathrm{V}$ kn.: Organizatsiya $i$ lechenie detey $s$ ortopedicheskimi zabolevaniyami i travmami [Pathogenetic substantiation of conservative treatment of bone cysts in children. In: Organization and treatment of children with orthopedic diseases and traumas]. Leningrad: Meditsina; 1990; p. 111-112.

21. Bogos'yan A.B., Tenilin N.A., Sosnin A.G. Sposob lecheniya kostnykh kist [The method of treatment of bone cysts]. Patent RU 2069995. 1996. 